\title{
Post-Colonial Africa and the World Economy: The Long Waves of Uneven Development
}

\author{
Fouad Makki \\ Cornell University \\ fmm2@cornell.edu
}

\begin{abstract}
The aim of this article is to examine the interactive dynamics of "Africa" and the "world economy" over the past half century. By relating the overarching developmental trajectory of the continent to the long-wave rhythms of the world economy, the article identifies three relatively articulated periods in the political economy of postcolonial Africa. The first, from circa 1960 to the late 1970s, was a period of state-led developmentalism enabled by the long postwar boom in the world economy and the embedded liberalism of the Bretton Woods system. A second period from circa 1980 to the turn of the new century was conditioned by the long downturn in the world-economy and a neo-liberal regime of accumulation that sought to re-structure and reintegrate Africa into a deregulated world market. The turn of the new millennium constitutes a new period in which neither the deep structural springs of the long downturn nor the neo-liberal project as such have been overcome; but their impact on Africa has been relativized by the emergence of East Asia as the new center of accumulation in the world economy. The resulting de-synchronization of the long-wave rhythms of the world economy has permitted a modest economic expansion in Africa within a largely extractive regime of accumulation and a wave of new enclosures that are profoundly reconstituting the social universe of Africa's primary producers.
\end{abstract}

Keywords: post-colonial Africa, capitalist world economy, long-waves, uneven development

The fiftieth anniversary of the "Year of Africa," marking the beginning of the end of European colonial rule in the continent, was commemorated in 2010 with a euphoria and exuberance reminiscent of the formative years of decolonization in the early sixties. Coming on the crest of a commodities boom that has seen average growth rates at an all time high, the commemorations were accompanied by a widespread sense of an African renaissance, and Africa's statesmen used the occasion to project a redemptive narrative of seamless progress. These self-congratulatory pronouncements came a mere decade after the Western media had contemptuously dismissed Africa as a "hopeless continent" whose very name was synonymous with primordial backwardness, recurrent ethnic wars, and self-inflicted inexplicable sufferings. ${ }^{1}$ While the

\footnotetext{
1 "Hopeless Africa" was the infamous heading emblazoned on the cover page of the May 2000 issue of The Economist. Such discourses are of course not simply the unwitting biases of the Western media. They form part of a

This work is licensed under a Creative Commons Attribution 4.0 United States License. Journal of World-Systems Research, Volume 21, Number 1, Pages 124-146, ISSN 1076-156X
} 
reports of the institutions of global governance generally shun such crudeness, their analytic conventions remain framed by a no less false antinomy between "Africa" and the "world" in which all that ails Africa is ascribed to the continent's own political or cultural failings. These seemingly contrasting positions share the implicit assumption that the condition of post-colonial Africa can be analyzed within terms exclusively internal to the continent itself. To suggest that the processes that constitute this condition have to be situated in relation to the historically constituted transnational arrangement of geo-political and economic relations that causally impinge on their specific forms and dynamics, is to risk scorn for presumably offering a defensive apologia or simply refusing to confront hard, if inconvenient, facts.

In contrast to these essentialist or reductionist accounts, the anniversary celebrations provide the occasion for a dispassionate analysis of the overarching trends in the political economy of post-colonial Africa set within the relational context of an evolving international capitalist order. Since at least the end of the nineteenth century, Africa has been the site of successive attempts by forces within and beyond the continent to remake its social ecologies in relation to the material and cultural underpinnings of a colonial and capitalist modernity. The range and density of these relational processes have varied over time, but no consideration of the political economy of the continent can be plausible without taking this world-historical relationship into account. Given the enormous scale and heterogeneity of the continent, these processes have of course never been uniform and Africa's constituent societies have not moved in complete synchrony with the oscillations of the world economy or the geopolitical shifts in the international order. But rather than a series of enigmatic anomalies, these disjunctures can be understood as intelligible variations within a common unevenly combined relational field of world capitalist development.

From the vantage point of this analytic framework, the half-century since decolonization can be roughly periodized into three distinct periods, each articulated with specific configurations of power and plenty in the world system. The first phase, from circa 1960 to 1980 , was dominated by processes of state formation and national development in the context of the long postwar boom in the world economy and the embedded liberalism of the Keynesian consensus. During this period, African societies registered a steady if modest economic growth and the expansion of health and education services that are particularly notable when compared with the record of the preceding eighty years of colonial rule. A second phase, from the turn of the 1980 s to the beginning of the new millennium, was shaped by the prolonged downturn in the world-economy and the imposition by the IMF of neoliberal structural adjustment programs designed to reintegrate a restructured Africa into a deregulated world economy. The upshot was nothing short of a "great depression" that arrested or reversed many of the social and economic gains of the first period. Each of these phases was shaped by different configurations of Pax Americana. As Alice Amsden (2007:1) tersely puts it, while the American Empire between 1945-1980 "lifted all boats" (albeit unevenly), the second merely "lifted all yachts" thereby accelerating inequality both within and between nations. The turn of the current century arguably constitutes a new period in which neoliberalism and the structural springs of the long downturn have not been overcome, but their impact on Africa has been relativized by the emergence of East Asia as a center of global accumulation. The consequent spatial disarticulation and temporal de-synchronization of the long-wave rhythms of the world-economy, has permitted a modest 
economic expansion together with a concerted drive to remake the continent through a renewed process of accumulation by dispossession.

While this rough periodization is generally uncontroversial, the conceptual framework suggested here - emphasizing the unevenly combined interactive dynamics of post-colonial Africa's political economy and the long-wave rhythms of the world economy - is arguably distinct. It uses a specific world-historical method to examine global processes through a regional lens, giving specificity to such processes and accounting for why the international order is a space of "uneven and combined development." Such a conceptualization makes possible a more relational analysis of Africa's political economy, and fundamentally recasts the conventional framing of the post-colonial epoch in terms of a series of linear transitions from a colonial to a national and then to a global mode of regulation. The first part of this article briefly expands on this conceptual framework through reflections on the long-term interactive dialectics of Africa and the world economy. Subsequent sections analyze the structural legacies of colonialism and each of the phases outlined above before a brief concluding note resumes the central argument. Some cautionary remarks are nonetheless necessary before proceeding. The dialectic of Africa and the world economy has to be understood as politically mediated and mutually conditioning. Given the asymmetries of power that underpin them, however, there can be little doubt which side has exercised the more decisive causal force. ${ }^{3}$ Secondly, there is obviously no one-to-one correspondence between political and economic processes, and the mediated relationship between them is typically characterized by an arrhythmic discordance. Lastly, it should be clear that this article makes no claims to comprehensiveness and is offered here as an empirically informed suggestive conceptual framework for analyzing the trajectory of post-colonial Africa in relation to the evolving structures of the world economy. As such, it constitutes no more than a set of preliminary reflections for more finely grained and differentiated studies of the unevenly combined patterns of social change in the continent.

\section{Africa and the World Economy}

The categories "Africa" and the "world-economy" are not self-evident units of analysis and each poses its own set of conceptual problems. As a cartographic expression, Africa has existed since Roman times, initially as a designation for North Africa, and by the first century of the C.E. for the continent as a whole. For most of the intervening period, this geographic designation was not accompanied by a common subjective sensibility. It was only within the relational space of the late nineteenth century Black Atlantic that the idea of "Africa" first acquired meaning as a shared structure of feeling. ${ }^{4}$ From the turn of the twentieth century, a series of Pan-African congresses crystallized this emergent continental consciousness as a means of expressing and mobilizing a transnational anti-colonialism. The idea of Africa then came to constitute a kind of "geoculture"

\footnotetext{
${ }^{2}$ For methodological reflections along the lines suggested here, see McMichael (2000) and Tomich (2004). For an extended elaboration of the idea of "uneven and combined development" as used here, see Makki (forthcoming $2015)$ and Rosenberg $(2006 ; 2010)$. For one attempt to apply the idea of uneven and combined development to the political economy of Africa, see Bond (2006).

${ }^{3}$ To give just one illustration of this asymmetry: the turnover of capital in just five of the largest multi-national corporations, \$526.1 billion, is about double sub-Saharan Africa's total of \$269.9 (Toussaint 1999: 26-27).

${ }^{4}$ Kwame Anthony Appiah suggests that, "Alexander Crummell and Edward Blyden began the intellectual articulation of a Pan-Africanist ideology, but it was W.E.B. Dubois who laid both the intellectual and the practical foundations of the Pan-African movement" (Appiah 1992: 28).
} 
in which the elements of a common history could override existing social, political and cultural differences. ${ }^{5}$ With decolonization, this conception became institutionalized in the Organization of African Unity without necessarily eliciting more than a semblance of the kind of imaginative attachment commonly associated with membership in the nation. "Africa" is therefore best understood as an idea whose substantive meanings have changed over time and whose history has more to do with interaction across world regions than with the eternal repetition of some essentialized cultural or social form.

Contemporary Africa is divided into fifty-four culturally heterogeneous and politically differentiated states that are moreover distinct in terms of their pattern of capital accumulation, their degree of industrialization and commercialization, and their rates of literacy and urbanization. Fifty percent of the continent's GNP is generated by only three states - South Africa, Egypt, and Nigeria - and half its population of more than a billion is concentrated in just seven countries. But for all this variation and unevenness, certain broad socio-ecological features whose longue durée significance become apparent when set against those of Eurasia, have critically shaped the general dynamics of change in Africa. Jared Diamond has for instance argued that Africa's north-south succession of ecological zones - desert, savannah, tropical rainforest, and veldt - greatly impeded the diffusion of domesticated plants and animals, whereas Eurasia's lateral spread of similar habitats facilitated it (Diamond 1999: 177-191). Jack Goody has in turn pointed out that the relative ratio of people to land in Africa, characterized by scarcity of people and abundance of land, sharply contrasts with the predominant pattern in Eurasia and accounts for why power was typically exercised directly over people rather than through the mediation of land. A common socio-political imperative under these conditions was the recurrent search for coercive or cultural means to arrest geographic mobility and fix people in place (Goody 1971; cf. Iliffe 2007). The importance of extended kin relations and various forms of coerced labor can in part be attributed to this socio-ecological determinant, just as much as collective desertion to uncharted terrain beyond was a common form of resistance: lateral movement providing an exit from vertical subordination. Modern state formation has consequently been crucially handicapped by this socio-spatial pattern of small pockets of settlements separated by wide expanses of sparsely populated territory, making the construction of effective territory-wide infrastructures of power comparatively more difficult (Herbst 2000).

All these works provide important insights into the long-term dynamics of social change in Africa even if they sometimes miss vital aspects of the differentiated texture of socioecological relations within the continent. But for all the specificities and commonalities of Africa's social and cultural formations, their asymmetrical insertion into the world market over the past few centuries overdetermined their developmental trajectories in crucial ways. Each phase in this process of incorporation represented a critical moment in the making of the modern world-system itself. The trans-Atlantic slave ships that carried an estimated twelve million Africans to the Americas - the largest forced migration in human history - were part of the original moment of primitive accumulation, when the colonial expropriation of Native Americans was conjoined with the enslavement of captive Africans to meet the labor imperatives of an emergent capitalist world (Rodney 1974). The late nineteenth century conjuncture of high

\footnotetext{
5 This "geoculture" has taken various forms, including the idea of "Negritude" famously articulated by Aimé Césaire and Léopold Sédar Senghor, whose anti-colonial political commitment was to non-national paths out of empire that could radically reconfigure and transcend the metropole-colony divide. See here the remarkable study by Gary Wilder (2015), a work of critical recuperation that sheds an entirely new light on the political ideas of Césaire and Senghor.
} 
imperialism represented the moment of the territorial-extractive imperative, when Africa's resources - such as rubber, copper, iron and bauxite - proved essential for the so-called second industrial revolution in the West (Mazrui 1999; Wallerstein 1986: 101-138). European state's late nineteenth-century drive to conquer new territories and extract resources was partly conditioned by these geopolitical considerations and was facilitated by the opening of the Suez Canal, the development of the steam ship, and the spread of telegraph and railway networks that together establish the late-nineteenth century as a global conjuncture of pronounced time-space compression. ${ }^{6}$

These successive phases of Africa's integration into the world market did not necessarily inaugurate a stadial and unilinear process of transformation from "traditional" to "modern" societies as modernization theorists once imagined. Nor did it imply that African societies had become capitalist by virtue of the exchange relations that henceforth tied them to the workings of the world market, as some dependency theorists had assumed. ${ }^{7}$ Over the past few centuries, African societies have certainly come into contact with the material and cultural underpinnings of a colonial and capitalist modernity, and this has had a decisive causal impact on their historical evolution. But they were not thereby drawn into a universal process of capitalist development driven by the rationalizing logics of modernity or the restless engine of the world market. Rather than radiating from some metropolitan center to remake all societies in its own image, historical capitalism has unfolded in distinct unevenly combined forms. The ways in which a given region interacts with the world economy is consequently a historical as much as a structural relationship. And the social formations that crystallized within this interactive process necessarily took varied forms that require concrete analysis rather than formulaic categorization.

Moreover, just as world capitalist development is patterned in complex ways across space, it is also differentiated by time, waxing and waning in a disjunctive temporality of cycles and waves. Two such temporal rhythms are often recognized: business cycles with a five to seven year duration that are in turn embedded in a second rhythm of long-waves of forty to fifty year duration. While there is no consensus on the precise mechanisms of these long-waves changes in the average rate of profit, the formation of world prices, the renewal of fixed capital, the application of new technologies, and cycles of social struggles have all been suggested - the temporal rhythm itself seems to be there, forming the regulative heartbeat of the world market (Mandel 1995; Kleinknecht, Mandel and Wallerstein 1992; Schumpeter 1961). These alternating patterns profoundly shape the relative amplitude of the normal business cycles so that in the expansive long-wave upturns tend to be long and deep while downturns are typically short and shallow. Precisely the reverse pattern obtains in the long-wave with a depressionary tendency. These long-waves thus condition the overall ebb and flow of investments, growth, employment and income in distinctive ways. As Ernest Mandel has argued, since the mid-nineteenth century we have had rapid expansion in the world economy from 1849-1875; slow expansion from 18751900; a new period of rapid expansion from 1900-1920 and near stagnation from 1920-40 (or 1945); and again a period of unprecedented expansion from 1940-45 to 1970-75 followed by a prolonged downturn thereafter. Mandel rightly emphasizes that these temporal rhythms are not

\footnotetext{
${ }^{6}$ The second industrial revolution generated its own movements of the laboring poor, this time into rather than out of Africa, as indentured Indian laborers were brought in to work the sugar plantations of Mauritius, the mines of South Africa, and the railway projects in East Africa; while urban retail markets became accessible to new immigrant merchant communities: Lebanese and Syrian in West Africa, Indian in East Africa, and Yemeni or Armenian in northeast Africa (Potts 1990).

${ }^{7}$ For a review of these competing theoretical approaches in relation to Africa, see Cooper (1993: 84-201).
} 
mechanically alternating phases of expansion and contraction driven by some ingenious clocklike mechanism. While the shift from an expansionary to a depressionary wave can be plausibly explained by the developmental tendencies of capitalism, the onset of a new expansive phase is conditioned by exogenous socio-political developments (Mandel 1995).

While explaining the temporal discontinuities characteristic of capitalist development, these long wave rhythms do not in themselves illuminate the spatially differentiated and contradictory quality of the particular phases themselves. A degree of homogeneity can be implied that subsumes regional unevenness within a diachronic succession of temporal phases. It is only through a more differentiated conception of the spatio-temporality of capitalist development, in which processes of capital accumulation are not just discontinuous but internally heterogeneous as well, that it becomes possible to appreciate the uneven and interwoven forms of socio-economic transformations. From this perspective, the world economy can be understood as a relational whole whose contradictory dynamics generate reciprocally determining social and political forms. As a global formation, it can be looked at structurally and synchronically in any given epoch, but its historical pattern of expansion and reproduction is necessarily shaped by the concrete unevenly combined conditions of its existence in different place-times. Viewed from this vantage point, it is evident that processes of commodification have proven remarkably adaptable to different social and institutional settings, and it may very well be that the core regulative rules of capitalism might be those governing the conversion of use value into exchange value, rather than the wage contract as such. It would of course be difficult to imagine the generalization of exchange value without the commodification of labor power, and it is precisely this contradictory unity of concentrated spasms of accumulation by dispossession and sustained if contested processes of commodification that together constitute the explanandum and the explanan of modern Africa's distinctive historical trajectory.

Figure 1. Kondratieff's Long Wave, Annual Averages, Ratio Scale

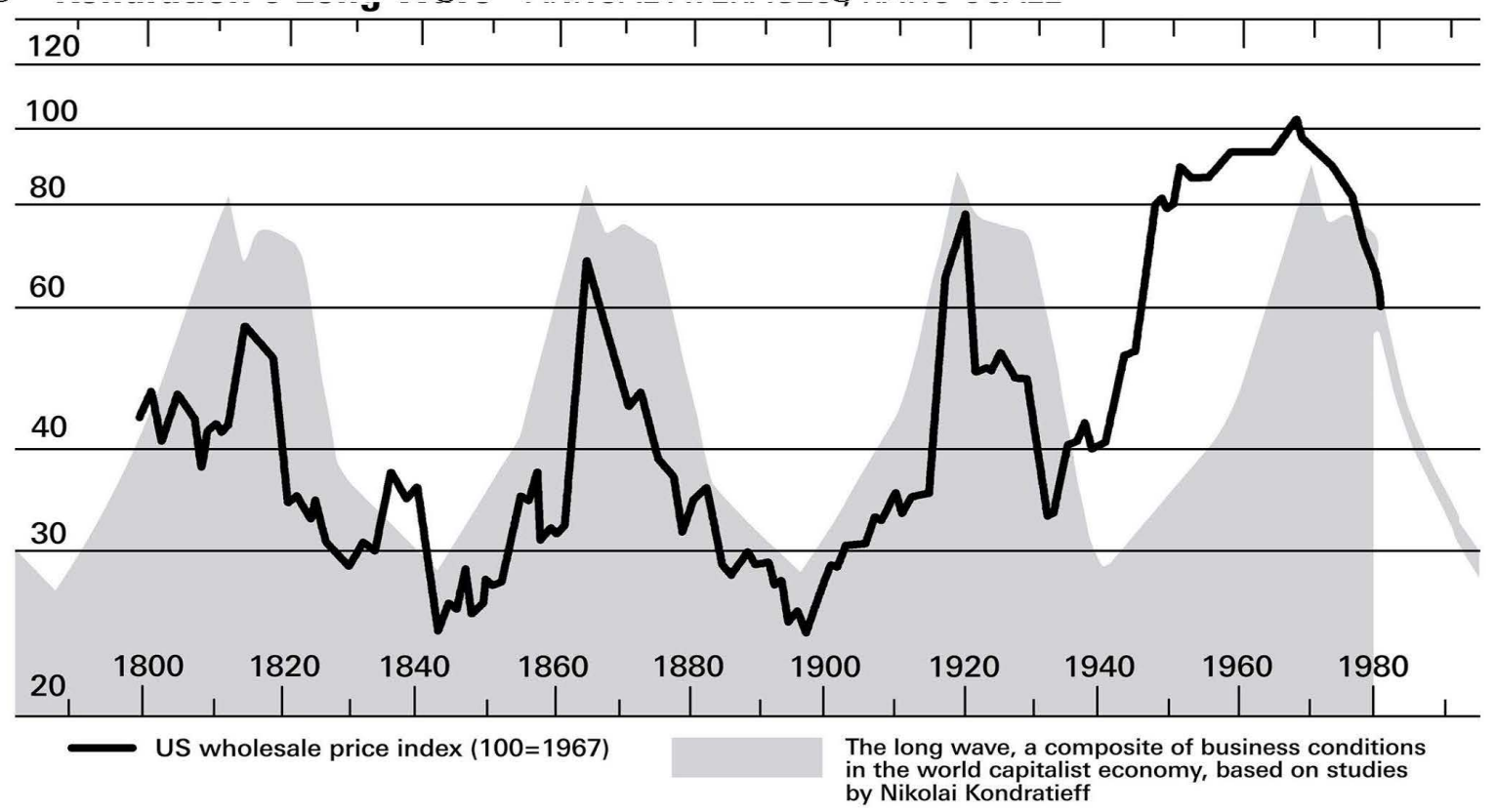

Source: Adapted from Knox and Agnew, The Geography of the World Economy, p. 114. 


\section{Colonial Capitalism and the Gate-Keeper State}

The Africa the Europeans colonized was not a flat space they could simply remake ex nihilo, and the transformations they introduced were shaped by the continent's complex social terrain as much as by the specificities of the colonizing powers. The particular social and political characteristics of the imperial metropoles from which colonial projects were launched conditioned the specific forms of state and economy that emerged across the continent. Unlike Britain and France, Portugal and Italy, for instance, were states based on pre-industrial infrastructures heavily dependent on agriculture, and they practiced a mode of colonial exploitation that differed markedly from the practice of the capitalist colonizers. While the industrial bourgeois empires exploited colonial possessions for raw materials and as markets for consumer goods, the former simply seized control of land or productive assets and enforced an advantageous exchange of primary commodities. But almost everywhere in the continent, the transition from an extractive predatory regime to a transformative imperialism was only partially realized, as Africans devised various strategies to assert their autonomy within the confines of uneven power relations.

With limited institutional capacity to penetrate local societies, and determined to "make the colonies pay for themselves," colonial states were largely restricted to holding the upper levers of power within the newly demarcated territorial units. This apparatus of power was most directly felt at certain strategic nodes - the areas of raw material production and the points of connection with the world market, which typically became the administrative centers of the colony. Linear railway lines connected the sources of agricultural or raw material production to the ports, and most revenue was collected there in the form of import and export duties. Colonial states were in this sense "gatekeeper states" situated astride the junction of the world market and the colonial territory and primarily engaged in rentier activities and control over the movement of people and goods in and out of the colony (Cooper 2002: 156). ${ }^{8}$ Beyond these administrative and extractive enclaves, states exerted limited control over the vast social spaces of the hinterland, where the exercise of authority was relegated to "traditional" intermediaries. Colonial leviathan was consequently a variant of an impersonal bureaucratic apparatus articulated with locally embedded relations of personal dependence and ultimately reliant on the coercive reserve of metropolitan power. This hybrid structure proved generally serviceable for projects of colonial exploitation and the forced mobilization of labor. ${ }^{9}$

Variations of this modular form of colonial power were implanted on a wide range of agrarian and agropastoral communities. But over time, as Samir Amin has suggested, three distinctive regional patterns crystallized across the continent: the Africa of the labor reserves, where migrant labor was enlisted in the gold, cooper, and diamond mines of southern Africa, or the coffee, tea and sisal estates of East Africa; the Africa of the colonial trade economy in parts of West and North Africa, characterized by the production of agricultural commodities for

\footnotetext{
${ }^{8}$ The term "gatekeepers" comes from General Obasanjo, military head of state of Nigeria from 1976 to 1979, who used it in reference to "the class of Nigerians who in effect hold state office for the sake of charging a toll on foreign enterprise seeking to do business in Nigeria" (1998: 211).

${ }^{9}$ The degree of violence that attended colonial conquest in Africa is sometimes forgotten. In German East Africa, for instance, the suppression of the Maji-Maji revolt witnessed the massacre of 200,000 to 300,000 Africans. The resistance of the Herero and San peoples in present-day Namibia was met with a genocidal extermination policy that virtually annihilated these populations (Steinmetz 2007: 135-242). In Libya, to take another example, colonial conquest "may have killed one-third of its people" (Iliffe 2007: 215).
} 
metropolitan industries; and the Africa of the concession companies in central and equatorial Africa where chartered companies used forced labor in quasi-plantation like systems (Amin 1972: 503-24; cf. Wallerstein 1986: 13-37). In nearly all these zones, the physical and social costs of reproducing labor power were underwritten by village subsistence production, allowing companies to pay exploitative "bachelor" wages (Wolpe 1995: 60-90). The hinterland also served as vast labor catchment areas for colonial road and railway construction, for the colonial mines, and for service as conscripts in the colonial army. But given the limited penetration of the money economy and wage relations, together with the existence of the open frontier, colonial states had great difficulty subjecting Africans to the rigors of capitalist discipline. The resort to forced labor and predatory plunder, especially in the first decades after imperial conquest, was partly conditioned by this reality. The most horrific instance of such a regime of colonial plunder was the Belgian Congo, where rubber tapped from the forest vines fetched super-profits at a time when demand in the world market had grown astronomically, but commercial rubber plantations had not yet matured to supply it. The brutal labor regime resulted in the catastrophic reduction of the Congolese population by almost half. But this was by no means an isolated instance of imperial barbarism. Leopold's Congo became a workable model for Portuguese Angola, the German Cameroons, the French Congo and parts of French Equatorial Africa, which all adapted "exactly the same system - including women hostages, male forced labor and the chicotte - with equally high death rates" (Marchal 2008: xvii). ${ }^{10}$

The partial shift from this extreme form of predatory accumulation to a routinization of colonial exploitation came in the aftermath of the First World War and the Great Depression, which led metropolitan states to initiate a big push for the development of the colonial economy. As imperial powers urged colonial administrators to expand commodity production and tie output and trade more directly to metropolitan needs, large investments were made commensurate with the extension of the economic role of the state. Some of these colonial development projects, like the groundnut scheme in British-ruled Tanzania or the cotton scheme in French controlled Mali, ended up as signal failures; while others, particularly those of cocoa, coffee, tobacco and small-scale cotton production proved profitable for colonial enterprises. Scale was not always the determining factor of success. The Gezira irrigation scheme extending over 400,000 hectares along the Nile south of Khartoum and cultivated by tenant famers and migrant laborers from West Africa, was producing as much as one-third of the world's longstaple cotton by the mid-1950s (Iliffe 2007: 222). The interwar years also saw the establishment by the Firestone Company in Liberia of the world's largest rubber planation.

Overall, however, late-colonial developmentalism proved politically and economically contradictory, and its lasting economic effect was the construction of a mercantilist or extractive economy based on the export of a narrow range of commodities. Politically, it generated conflicts imperial rulers could not readily control and gave anticolonial movements a powerful impetus to take up the mantle of development as a project that only sovereign societies could accomplish. The British attempt to placate anticolonial activists through limited representation in colonial councils, or the selective granting of citizenship status to evolués in French Africa, only served to underscore the limits of the colonial framework for promoting material progress or civic rights (Cooper 1996). These late colonial contradictions fostered growing resistance across the continent, and by the late 1950 s European imperial powers were beginning to retreat,

\footnotetext{
${ }^{10}$ For a powerful account of the Belgian system of forced labor, see also Hochschild (1999).
} 
convinced they could transfer power without seriously disrupting the deeply embedded structural relations and hierarchies established over the previous sixty to eighty years. ${ }^{11}$

\section{The Post-War Boom: From Colonial to National Development}

The newly independent states of Africa inherited both the extraverted economy and the gatekeeper functions of the colonial state. Nationalist leaders were initially hopeful they could use their newly acquired state power to remake these colonial inheritances and reorder them to meet the needs of their citizens. Almost invariably however, they came up against the limits of national sovereignty in a world structured by a colonial division of labor and a hierarchically organized interstate system. And despite the desire for equidistance from the superpowers enunciated at Bandung in 1955 and the non-aligned movement in 1962, they were handicapped by the limited capital, technology, and skills at their disposal and had great difficulty navigating the conflicting pressures of the Cold War moment. After the late colonial period in which contrasting imaginaries of a post-imperial future and different notions of sovereignty had vied against each other, the post-colonial state converged on the international norm of the nationstate. The consequent attempt to institute a unitary state and an integral nationalism against the plural colonial society typically led to the establishment of one party authoritarian states that became vehicles for asserting a statist commonality.

Decolonization had mostly transpired in the context of a long-wave expansion of the world-economy - albeit the tail end of it - and a postwar settlement of embedded liberalism institutionalized in the Bretton Woods system. This international order was underpinned by the United States, which had emerged as the global hegemon through the demonstration of its military might in the Second World War and an industrial capacity that had virtually doubled during the war years (Davis 1986: 190). With the demise of colonial empires, the postwar global order was reconstituted into an interlocking system of nationally managed economies under the sovereignty of the dollar. The abstraction of the market that had served as the normative construct of pre-Keynesian economics was replaced by the notion of economic systems whose spatial limits coincided with the territorial boundaries of nation-states. This gave states considerable latitude to determine domestic interest rates and fix the exchange rates of their currencies in accordance with their development strategies. Motivated by the geopolitical goal of containing communism, the United States signaled to the emerging Third World a new postcolonial orientation of "democratic fair dealing" supported by development aid that however essentially served to facilitate their deeper integration into the world market.

This postwar institutional framework enabled an unparalleled expansion of the world economy through the reconstruction of fixed capital and the generalization of neo-Fordism. GDP and labor productivity grew almost twice as fast as in any period since 1820 , and there was a rapid acceleration in the rate of growth of the capital stock. The volume of trade grew eight times faster than in the period 1913-50 and was twice as large as in the century from 1820. Output of

\footnotetext{
${ }^{11}$ Decolonization was not everywhere a peaceful transfer of power. At the height of the colonial war in Algeria, some 400,000 French troops were deployed resulting in as many Algerian casualties and the displacement of a further two million people. In Kenya, where the British settler population exceeded 20,000, the repression of the socalled Mau Mau movement witnessed the internment and torture of tens of thousands of Kenyans. The late decolonizing Portuguese Empire and the white settler colonies of southern Rhodesia, Namibia and South Africa were all scarred by protracted violence.
} 
manufactures more than quadrupled between the early $1950 \mathrm{~s}$ and $1970 \mathrm{~s}$, and world trade in manufactures grew eight-fold (Glyn, Hughes, Lipietz, Sing 1991: 41-42). In Africa, the first two decades after 1960 witnessed a significant if uneven economic expansion and a relatively enlarged, if still limited, provision of education and health services. States subsumed foreign trade to national priorities and sponsored import-substitution industrialization (ISI) through the production of consumer goods for the domestic market. Fiscal and monetary policies, tariff barriers, and preferential taxation were used to get foreign investors to manufacture products domestically, and where they could - as in Algeria and Nkrumah's Ghana - they established state-owned heavy industry. Between 1965 and 1973 the industrial sector as a whole expanded twice as fast as GDP, and although much of this expansion was in the mining sector, manufacturing in food processing and textiles also grew at an annual rate of seven percent between 1960 and 1980 (Cooper 2002: 99-103).

But over the long run, import substitution didn't advance as African states had hoped. The primary phase of import substitution was relatively brief, lasting barely a decade before the mid-seventies crisis in the world-economy short-circuited its conditions of possibility. Limited institutional capacity, small domestic markets, shortages of skilled labor, and weak or nonexistent infrastructure inhibited ISI initiatives and failed to stimulate backward, forward, or lateral linkages, or to attract foreign capital outside the extractive enclaves. Productivity differentials in the world market, and the steady decline in the terms-of-trade for primary products, further restricted access to capital necessary for the importation of capital goods and technology. ISI policies also tended to insulate domestic industries from competition, subsidizing the production of more expensive or inferior goods than that available on the world market. These structural limits were exacerbated by the veritable corruption of state elites who used ISI policies to extend their patron-client networks rather then enhance production (Leys 1996: 107134). But it was ultimately the onset of the long depressionary wave that effectively stifled economic growth, and by 1980 Africa was deindustrializing as excess manufacturing capacity in the world economy, and the development of new synthetic alternatives for some of Africa's primary products, blocked industrial advance.

In the extensive rural hinterland that was the social universe of African peasantries, colonial policies were primarily concerned with the promotion of commodity production, the expropriation of land for settlers, and the delimitation of customary land and communal forms of tenure. As science and technological know-how became the new "measure of man," late-colonial states also deployed new conservation discourses to displace African producers (Adas 1989). The post-colonial period saw a continuation of this developmentalist techno-science emphasizing questions of environmental degradation and "scientific management" to reconstitute tenure relations (Berry 2002). But the prevailing communal or smallholder systems, and the limited institutional capacities of states, frustrated the various projects intended to remake the moral economy of African peasantries. The latter were by no means homogeneous or undifferentiated, and their social and cultural forms were shaped by the particular nature of their ties to states and markets, their specific gender regimes and household structures, and the status and extent of migrant labor in the agrarian economy. State taxation policies and peasant responses to it were also crucial in determining social configurations in particular locales (Isaacman 1993). In general, however, the specific form of peasant differentiation was determined by two contrasting modes of accumulation: accumulation from below, which generated gradual differentiation in relation to market imperatives or opportunities; and accumulation from above that required "an element of state extra-economic coercion" (Mamdani 1986: 42-43). While the latter form 
became increasingly prevalent over time, it stopped short of the kind of large-scale enclosures and mass eviction of peasant households that characterized the settler colonial projects of Southern Africa. Africans "used mobility, kinship networks, and the ability to move between modes of economic activity to avoid too much dependence on white employers in mines or cities or would-be African capitalists in the countryside. It was mainly in South Africa that a racialized version of Marx's primitive accumulation took shape" (Cooper 2014: 21).

While peasant production was unevenly integrated into market networks, the conditions and instruments of production remained largely uncommodified, limiting the capacity of states or capital to impose new production regimes or work rhythms. African peasantries, as Göran Hayden once put it, remained largely "un-captured" (Hayden 1980). The major factors determining agrarian futures under these conditions was the local agricultural cycle, which while not autonomous from market cycles, was conditioned mostly by changing rainfall patterns, extent of land degradation, and growing demographic pressures on plot sizes. Erratic rainfall patterns exposed farmers to periodic harvest crises that burgeoned into mass famines in regions where changing tenure relations and the substitution of commercial for subsistence crops had altered the adaptive social mechanisms of reciprocity and redistribution (Bernstein, Crow, Mackintosh 1990: 13-31; 54-68; 149-62). In Mali, for instance, production of foodstuffs dropped from 60,000 tons in 1967 to 15,000 tons in 1975 as a result of the expansion of cash crops such as cotton and peanuts, although the revenue these generated could not cover the costs of expanded food imports (George 1976: 38-39). Global climate change and desertification likewise saw the Sahara expand by sixty miles over forty years, provoking the southward movement of nomadic groups and catalyzing social and resource conflicts along the desert frontier. The Darfur crisis is perhaps the most widely publicized instance of such a crisis, which was exploited by the Sudanese regime for its own narrow political ends, catapulting what was a crisis over resources into a major social catastrophe (Mamdani 2009).

In both the industrial and agrarian sectors during the first two decades after independence, the state was unquestionably the central agency of development; but virtually nowhere was it institutionally capable of sustained structural intervention. The reasons for this vary from one state to another, with the most common explanatory approaches emphasizing the handicaps associated with colonial origins and the problematic inheritance of arbitrary boundaries that have made projects of state formation exceptionally difficult. ${ }^{12}$ Others, such as Jean-Francois Bayart (1993), have highlighted the historicity of African states and the active presence of longue-durée patronage networks in their organizational and political cultures. The majority of post-colonial African states arguably represent particular articulations of these two dimensions, institutional amalgams that have proven to be exceptionally vulnerable to periodic convulsions as tragically exemplified at its most extreme by the Rwandan genocide. Given their structural dependence on the narrow social and revenue base of enclave economies, almost all these states have also been highly susceptible to the repeated knockout actions of organized militaries (Murray 1966: 35-59). In the forty years before the turn of the new millennium, some two hundred aborted or successful coups had occurred across the divided political landscape of the continent (Ben Barka and Ncube 2013). Cold War geopolitics and covert action have certainly played a critical role in these coups d'état, a fact retrospectively confirmed by the relative retreat of the praetorian guards and the partial democratic openings - minimally conceived as a set of norms and discourses - that attended the end of the Cold War.

\footnotetext{
${ }^{12}$ See here the illustrative exchange between Basil Davidson and Mahmood Mamdani (1993) over the former's controversial study, the Black Man's Burden: Africa and the Curse of the Nation-State.
} 
Placed in a longer perspective, it is possible to argue that the first two decades after decolonization registered discernable if modest gains that the uniformly negative and undifferentiated portrayal of post-colonial Africa conveniently elides, projecting back into this era the reversal of fortunes associated with the neoliberal reaction of the 1980s. Through the end of the 1970s, projects of national development were not without tangible benefits and Africa as a whole achieved regular if unspectacular growth rates, averaging 2.4 percent between 1950 and 1975. In the twenty-three years between 1960 and 1983, African states quadrupled the meager primary school enrollment rates they had inherited from eighty years of colonial rule. Secondary school enrollment multiplied six-fold and the number of university students increased twentyfold (Iliffe 2007: 293-94). Parallel gains in health care saw infant mortality rates cut by half and average life expectancy increase from forty to fifty-two years before AIDS-induced declines reversed the trend. Agriculturally, it is often forgotten that state subsidies helped to increase production levels and Africa had become a net food exporter by the turn of the 1970s (FAO 2011: 49-51). With all the limitations of national political sovereignty, the relatively favorable international climate of the period enabled many African states to initiate projects of social transformation and to redirect their national resources to meet the needs of their citizens.

\section{The Long Downturn and Neo-liberal Globalization}

By the late $1960 \mathrm{~s}$, the long postwar boom in the world economy was beginning to show signs of exhaustion, culminating with a synchronized recession in 1975 that signaled the onset of a long depressionary downswing. The remorseless increase of overcapacity in the manufacturing industries saw overall rates of profit, investments, and growth decline, and US economic supremacy came under challenge from German and Japanese competitors that had made a remarkable recovery during the boom years (Brenner 2006). In the context of this intensified competition and the budgetary pressures induced by the Vietnam War, the US turned to borrowing from abroad to meet its international obligations. As it moved from being the world's largest creditor to its largest debtor, it was obliged to give up the gold standard in 1971, and two years later the international system of fixed exchange rates and control over capital movements were abandoned. This unleashed a speculative boom that fostered extreme instability in currency markets, and as stagflation set in, the price of primary commodities plummeted, ruining producers and states in Africa that were heavily dependent on raw material exports. The one major commodity that was shielded from the price recession was crude oil and the petrodollar windfall generated by the first oil shock of 1973 was re-circulated by the international commercial banks as loans to Third World states. This lending spree drove up total international debt to previously unimaginable levels (Strange 1987).

Most African states used the loans to finance import bills for industrial technology, equipment goods, and food, temporarily staving-off the worst effects of the structural crisis in the world-economy. As the second Brandt Report (1983: 25) pointed out, "the developing countries' imports from the North, partly financed by their commercial borrowing, helped to prevent the recession in the industrial countries from getting worse, sustaining production and employment

... Today that effect is reversed ... as major countries in Africa and Latin America run short of foreign exchange". The non-reciprocal trade protocols of the Lome Convention likewise allowed African states to retain access to European markets without foregoing their protectionist ISI policies and their subsidies to local farmers. But in the context of deepening global recession, 
demand for their products continued to decline, and the slashing of the money supply by the US Federal Reserve in 1979 raised the prime interest rate almost overnight. The resulting "redirection of capital flows to the United States turned the flood of capital that Southern countries had experienced in the 1970 s into the sudden 'drought' of the $1980 \mathrm{~s}$... probably the single most important factor in shifting competitive pressures from North to South and in provoking a major bifurcation in the fortunes of Southern regions in the 1980s and 1990s" (Arrighi 2007: 147).

Figure 2. GNP per capita and GNP per capita growth in Sub-Saharan Africa, 1960-1998

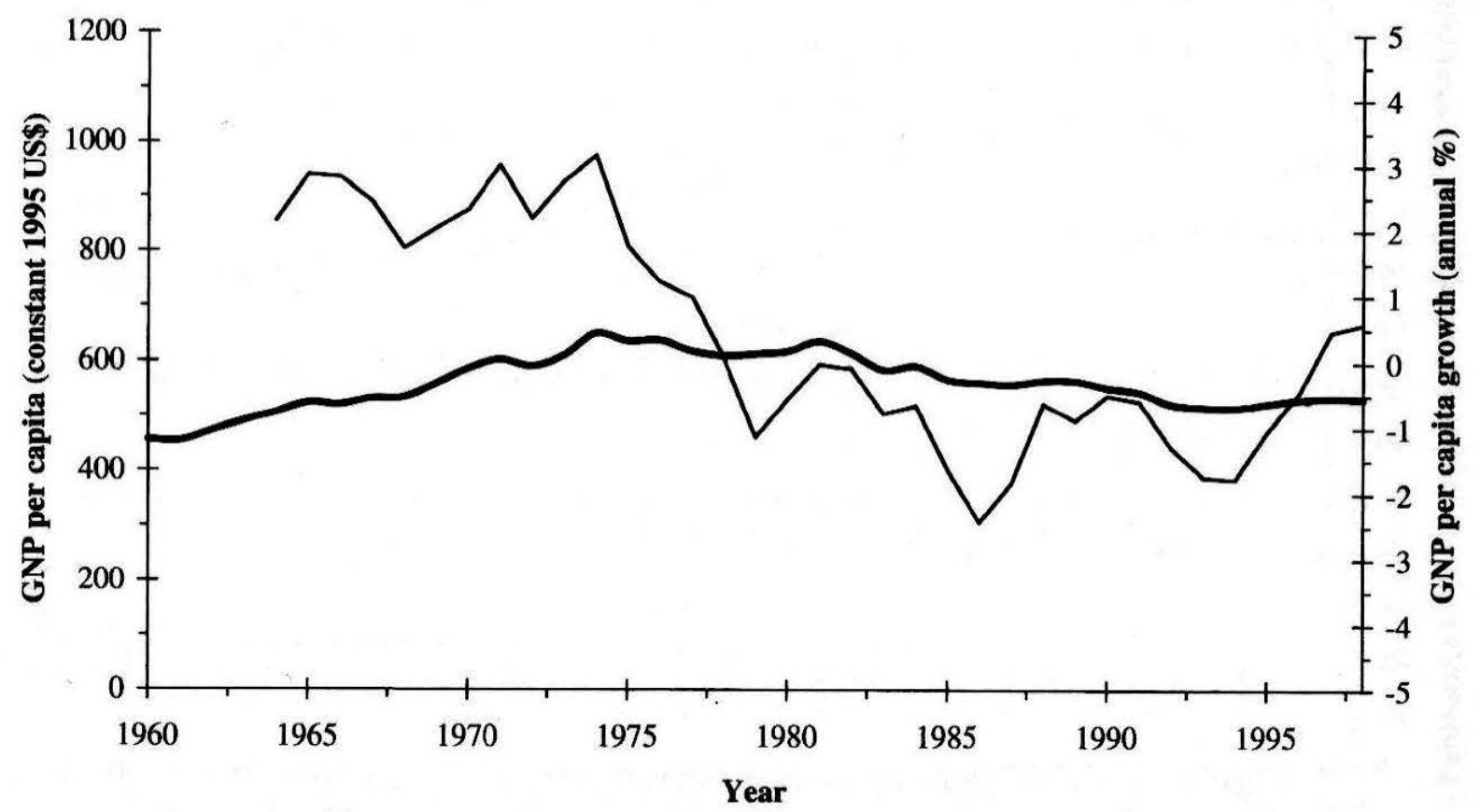

GNP per capita ___ GNP per capita growth (5-year moving average)

Source: Frederick Cooper, Africa since 1940, p. 93.

Faced with the collapse of commodity prices and declining per capita incomes, African states increased their borrowing abroad until servicing the debt led to severe balance of payment difficulties that forced them to turn to the IMF. As a condition of further support, the IMF imposed structural adjustment conditionalities that subjected African states to a neoliberal tributary regime and financial serfdom that effectively crippled social programs once viewed as emblematic of development. As deregulation became the order of the day and the debt service burden more than doubled from 11.8 percent to 24.5 percent (Bienefeld 1991: 13), Africa's per capita income declined by thirty percent (Arrighi 2012: 36); its share of world exports fell from six percent in 1980 to two percent in 2002, and its share of world imports declined from 4.6 to 2.1 percent (UNCTAD 2003: 1). Even in the so-called "miracle" economies of the structural adjustment era, such as Kenya, GDP per capita fell to 0.4 percent from its average of three percent between 1965 and 1980; while debt servicing absorbed one-third of export earnings. In Côte d'Ivoire, the corresponding "success" story in Francophone Africa, GDP declined by an 
average 3.2 percent in the 1980s as the "Ivorian miracle became a mirage" (Iliffe 2007: 263). Moreover, outside of South Africa, foreign direct investment, which was a key rationale for promoting structural adjustment, declined sharply and after 1980 African countries as a whole were less integrated into global markets than they were in the era of "national development".

Over the debris of international Keynesianism and state managed national economies, neoliberal globalization emerged as the reigning orthodoxy. This political ideal of a world in which all states shared a common normative commitment to a single global market provided a convenient alibi for states embracing the neoliberal agenda that became codified in the Washington Consensus. This signaled a major reversal in the analysis of development from a global to a purely national frame of reference, and from historical-structural explanatory frameworks to a focus on a-historical performance assessments (Gore 2000). African states were powerless in the face of this radically disempowering creed and unrestricted capital flows and the dismantling of national regulatory frameworks undermined what little economic sovereignty they had previously exercised. ${ }^{13}$ Comparatively, sub-Saharan African countries were the hardest hit especially because of their greater dependence on primary commodities whose value relative to that of manufactured imports was halved after 1980. Between 1986 and 1989, the fall in the terms of trade meant a loss of income for Africa of $\$ 55.9$ billion (Toussaint 1999: 97), and African countries reacted to this decline by increasing the volume of their exports by fifty percent between 1985 and 1992. But since the prices they could fetch for their products were steadily dropping, they faced a growing balance of payments crisis and a sharp reduction in their share of global purchasing power (Toussaint 1999: 196).

The case of Nigeria, where the oil enclave had limited linkages to the rest of the economy, exemplified this structural crisis. The oil price hikes of 1973 and 1979 overvalued Nigeria's currency to the point that "cash-crop exports collapsed while cheap manufactured imports undercut local industry. Then the international depression and a decline in oil prices in 1983 almost halved public revenue, created a foreign exchange crisis, boosted public borrowing and inflation, reduced industrial capacity utilization below forty percent, and threw the economy into disorder that still reigned a decade later" (Iliffe 2007: 263). Socially, structural adjustment programs undermined public health and education systems across the continent (see Table 1). In Ghana, an IMF poster state of the 1980 s, child mortality actually increased during this period and 50,000 cases of yaws - "a disease of poverty supposedly eradicated before independence" - had been reported (Iliffe 2007: 294). Tuberculosis, cholera, and yellow fever all became more prevalent as grinding poverty and deep cuts in public health programs made access to medicines evermore contingent on income at a time when the rate of decline in the per capita income of the poorest twenty percent was twice that of the population as a whole (UNCTAD 2001: 53). In Zambia, once considered a "middle-income" country with a booming industrial zone along its cooper belt, average GNP declined by 3.1 percent in the 1980 s, and by 1995 Zambia's external debt reached $\$ 650$ per capita, almost double its GNP per capita of $\$ 370$ (Ferguson 1999: 9).

Neoliberal globalization and growing inequality were also at the source of the massive increase in the brain drain from Africa. In the face of a sustained laissez-faire onslaught on social

\footnotetext{
${ }^{13}$ This shift was immediately apparent in the competing policy perspectives of the OAU's Lagos Plan of Action and the World Bank's Berg Report, both issued in 1980. While the former was informed by the earlier UN call for a New International Economic Order; the latter was emblematic of the new neoliberal orientation (see the discussion in Arrighi 2002; Ferguson 2006: 69-88). Following the IMF administered shock treatment "development" was transfigured by the World Bank into a systematic program for instituting the enabling conditions for capital accumulation. See here the crucial study by Paul Cammack (2004: 189-211).
} 
programs and the unraveling of the development project, emigration reached new levels as political instability, huge wage differentials, and a narrowing social horizon led to a phenomenal brain drain from the continent. The impact of this was most directly felt in the smaller African countries where in 2010 the proportion of those with higher education that were emigrating was forty-three percent for Zimbabwe, forty-one percent for Mauritius, and thirty-six percent for the Republic of Congo. For several other countries, including Burundi, Lesotho, Malawi, Mozambique, Namibia, Niger, and Tanzania the proportion of the highly educated was more than twenty times that of any other social group; while for Cameroon, Ghana, Kenya, Morocco and Senegal it was about fifteen times higher. All in all, in 2010-11 there were some three million Africans with tertiary education in the European Union (OECD-UNDESA 2013: 3).

\section{Table 1. Education: Gross enrollment rates in Sub-Saharan Africa, 1960-1997 (percent)}

\begin{tabular}{l|l|l|l|r|c|c|c|c|c}
\multirow{2}{*}{ Year } & \multicolumn{4}{|c|}{ Primary } & \multicolumn{3}{c|}{ Secondary } & \multicolumn{3}{c}{ Tertiary } \\
\cline { 2 - 10 } & Male & Female & Total & \multicolumn{1}{|c|}{ Male } & Female & Total & Male & Female & Total \\
\hline 1960 & 54.4 & 32.0 & 43.2 & 4.2 & 2.0 & 3.1 & 0.4 & 0.1 & 0.2 \\
1980 & 88.7 & 70.2 & 79.5 & 22.2 & 12.8 & 17.5 & 2.7 & 0.7 & 1.7 \\
1997 & 84.1 & 69.4 & 76.8 & 29.1 & 23.3 & 26.2 & 5.1 & 2.8 & 3.9 \\
\hline
\end{tabular}

Source: Adapted from World Bank, Can Africa Claim the 21st Century? (Washington, DC: World Bank, 2000), p. 106

The perversity of this logic in which the poorest countries of the world were losing their educated few to the richest zones of the world is particularly evident in the health sector. An OECD (2007: 173) study of the "medical brain drain" revealed that there were some 49,000 African doctors and 69,700 nurses working in the OECD countries in 2000, with crippling implications for the health sectors of African countries. In some states, fantasies of emigration have become so widespread that they have essentially eclipsed imaginaries of national development, as migration across the frontier of global inequality displaces prospects of social advance within them. According to Charles Piot, "It would not be exaggerating too much to say that everyone in Togo is trying to leave - by playing the lottery, by trying to get into European or American universities, by arranging fictitious marriages with foreigners, by joining churches that might take them abroad, by hoping to be signed by a European soccer team, by joining the fan club that accompanies the national soccer team overseas" (Piot 2010: 4).

These high rates of emigration have been accompanied by a significant increase in the inflow of remittances, amounting to $\$ 60.4$ billion in 2012 and constituting the largest source of external finance to Africa (Ncube 2013). ${ }^{14}$ But while these remittances are an important source of disposable income for millions who depend on them for their everyday needs, including essential health and schooling expenses - two areas particularly affected by structural adjustment programs - they have had little cumulative impact on productive capacity as such. The increased inflow is moreover compensated for by massive capital flight from the continent. According to the Chief Economist of the African Development Bank, "close to $\$ 1.4$ trillion were drained out of Africa" in the period from 1980 to 2009, far in excess of the total inflow of foreign aid,

\footnotetext{
${ }^{14}$ Nigeria and Egypt together received 64 percent of the total remittances to Africa, $\$ 21$ and $\$ 18$ billion respectively (African Economic Outlook, 2014).
} 
investments, and remittances (Ncube 2013; cf. UNCTAD 2000: 19, Table 4). Concurrent with capital flight and the brain drain, there has been a phenomenal expansion of NGOs in Africa, absorbing a good portion of international aid and in some instances effectively setting the development agenda. Although the great diversity of NGOs makes generalization somewhat difficult, there is no mistaking that their exponential growth since the turn of the $1980 \mathrm{~s}$ has been closely correlated with the rolling-back of the state's economic role. Their substantive function has been to serve as surrogates for states marginalized by neoliberal policies, sometimes even augmenting this by posing as elements of African civil societies. By the early 1990s, an estimated 100,000 expatriates were working in the proliferating network of NGOs in Africa (Mkandawire and Soludo 1999: 37).

\section{China, the Commodities Boom, and the New Enclosures}

The neoliberal landslide in the 1980 s was certainly not uniform. The international mechanisms of uneven and combined development promoted some regions and demoted others (see Table 2). While the exceptional performance of East Asia has generated ongoing debate about the reasons for this divergence and the consequent disarticulation of the long wave rhythms of the world market, both the Cold War on whose frontlines they were situated, and transformations initiated by Japanese colonialism and sustained by the dirigiste policies of the post-colonial states, will necessarily have their place in any balanced account. Deliberate policies aimed at fostering pragmatic distortions of the market, and the imposition of high but flexible tariffs, make it clear however that their exceptional growth rates had little to do with neoliberal prescriptions for a night watchman state and for getting "prices right" (Wade 1996: 3-37; Arrighi 2007).

\section{Table 2. GNP per capita for region as \% of core's GNP per capita *}

\begin{tabular}{lrrr} 
Region & 1960 & 1980 & 1999 \\
\hline Sub-Saharan Africa & 5 & 4 & 2 \\
Latin America & 20 & 18 & 12 \\
West Asia and & 9 & 9 & 7 \\
North Africa & & & \\
South Asia & 2 & 1 & 2 \\
East Asia (w/o China & 6 & 8 & 13 \\
and Japan) & & & \\
China & 1 & 1 & 3 \\
South & $\mathbf{5}$ & $\mathbf{4}$ & $\mathbf{3}$ \\
& & & \\
North America & 124 & 100 & 101 \\
Western Europe & 111 & 104 & 101 \\
Southern Europe & 52 & 60 & 60 \\
Australia and NZ & 95 & 75 & 73 \\
Japan & 79 & 134 & 145 \\
North (=core) & $\mathbf{1 0 0}$ & $\mathbf{1 0 0}$ & $\mathbf{1 0 0}$
\end{tabular}

* Based on World Bank data at current exchange rates Source: Arrighi, Silver, and Brewer (2003) 
China's high-speed growth since the eighties shares certain salient features with the wider regional pattern in East Asia, including an agrarian reform that did away with traditional landlordism; an abundant flow of cheap yet literate labor; a high rate of household savings; a strongly dirigiste state intervening in factor markets; and a prodigious export drive (Anderson 2010; Arrighi 2007). ${ }^{15}$ The rise of China as the workshop of the world, together with the global crisis triggered by the financial collapse on Wall Street in 2008, has set-off a new scramble for Africa's resources - both mineral and farmland. With " 42 percent of the world's bauxite, 38 percent of its uranium, 42 percent of its gold, 73 percent of its platinum, 88 percent of its diamonds, and around 10 percent of its oil" (Carmody 2011: 2), foreign direct investment has been steadily increasing, with net inflows estimated at eighty billion for 2014, up from fortythree billion in 2013 (AfDB 2014). Much of this investment is in the extractive sectors, primarily the new offshore oil reserves along the West African coast, which has been fueling Africa's GDP growth rates over the past decade, averaging 6.5 percent prior to 2008 and 5 percent thereafter (IMF 2013:3). While Chinese and Indian investments are expanding considerably, measured in value terms, they are largely concentrated in manufacturing and services rather than raw material extraction, which constitutes only a quarter of East Asia's total investments in Africa. For all the heightened rhetoric about the Chinese and Asian takeover of Africa, the Asian share of foreign direct investment was only twenty four percent of the 2010 total, as compared to forty one percent for the European Union, and twenty three percent for North America (UNCTAD 2013: 6). And although China has now become Africa's largest trading partner and an estimated one million Chinese reside in the continent, as of 2004 the leading Asian investors in Africa were Singapore ( $\$ 3.5$ billion), India ( $\$ 1.9$ billion) and Malaysia ( $\$ 1.9$ billion), followed by China, Korea and Taiwan. In the crucial oil sector, where African oil is estimated to make up twentyfive percent of North American imports by 2015, it is still EU and American capital that are dominant. $^{16}$

Investors from the emerging BRICS (Brazil, Russia, India, China and South Africa) are of course no more enlightened than those from the West. They are all without exception pursuing their national strategic or private economic interests, and the Chinese projection of "soft power" is largely designed to facilitate political alliances with an eye to preferential terms for trade and investment (Pádraig 2011: 65-94; Lee 2014). ${ }^{17}$ The "barter system" through which some Chinese contracts are arranged, however, require careful consideration insofar as they entail construction of infrastructure - from roads and railways to dams and power plants - and as such constitute a form of remuneration for African resources that cannot be readily siphoned-off by kleptocratic elites. This is particularly important given that the countries that have attracted the bulk of recent foreign investments have been those with "the most violent and corrupt states" (Ferguson 2006, p. 196). Politically, this new scramble for resources has unleashed a profound reconfiguration of state sovereignty and territoriality. The emerging "low overhead model," as James Ferguson calls

\footnotetext{
${ }^{15}$ De-synchronization does not mean disconnection. If anything, the export-oriented industrial dynamism of East Asia is crucially dependent on the large US and Eurozone markets, which still command the bulk of effective purchasing power in the world market.

${ }^{16}$ With the recent discovery of oil deposits in Ghana, Kenya and Uganda, there are now a total of thirteen oilexporting countries in Africa, and the continued attempts by the US, unsuccessful thus far, to establish an "Africa Command" on the continent is tied to this growing dependence on African oil and the perceived threat to Western interests posed by China.

${ }^{17}$ For an analysis of the complexity of Africa-China relations and its counter-hegemonic potential, set within a sharp critique of neoliberalism, see Quan (2012: 115-152).
} 
it, has recomposed some national states into virtual company states dependent on extractive enclaves secured by foreign mercenary outfits. Angola, which in many ways typifies this trend, receives over eight billion dollars annually from oil, but it was eleven billion dollars in debt in 2005, and unable to secure IMF backing for further loans, turned to commercial banks for oilbacked credit at higher rates of interest, effectively ceding not only "the looting of revenue from current production, but the mortgaging of future revenues for years into the future" (Ferguson 2006: 199). This scandal is by no means an isolated instance of a particularly rapacious predatory state. A UN report notes that "Nigeria has exported over seven hundred billion dollars in oil between 1980 and 2010 - and yet the country's per capita income is barely above the average for Africa. And despite having one of the highest GDP per capita, Equatorial Guinea is still only ranked 136 in the United Nations Human Development Index" (United Nations 2013: 2).

Clearly, not all African states have descended into such ruthless machineries of plunder. In countries like Kenya, Ghana, South Africa, Ethiopia, and Botswana, capital accumulation is embedded in a dense social network and institutional order. But even here there are reasons to be skeptical of any cumulative advance in the direction of social investments and economic diversification. The share of manufacturing in Africa's GDP has actually declined from 15.3 percent in 1990 to 10.5 percent in 2008 , while its share of global manufacturing value added diminished to a mere 1.1 percent (UNIDO 2011: 14). A staggering 50 percent of Africa's exports are processed externally and the prospects for reversing this concentration on low value added primary extraction appear limited. As a UN report observes, the "international economic environment has changed significantly since the Newly Industrializing Economies of South-East Asia embarked on their industrialization programs. African countries now have to operate within the framework of WTO disciplines (backed by a rigorous enforcement mechanism), which limit the use of instruments deployed by the NIEs, the special and differential treatment measures notwithstanding" (UNCTAD 2003: 61-62). The new commodity boom is thus essentially reinforcing Africa's position in the international division of labor established during the colonial era, although even here African states have been losing their competitive advantage in key commodities such as cocoa, tea and coffee to producers in Asia and Latin America (Southhall and Melber 2009). Similarly, the viability of smallholder cash crop production has been undermined by the structure of agricultural subsidies in the global north. African cotton growers have for instance been effectively marginalized in the world market by heavily subsidized US production, despite the fact that the cost of producing a pound of cotton in a country like Burkina Faso is less than a third of that in the United States (twenty-one as opposed to seventy-three US cents). The social effects of this widespread ruin of primary producers is emblematically illustrated by Mali, where some three million cotton growers in 160,000 farms generate as much as thirty-eight percent of the country's total export revenue (Fair Trade 2010).

The current world economic, food and energy crises has also unleashed a new wave of land grabbing as agribusinesses and states acquire land to expand production for external markets or, more perniciously, for purely speculative purposes in the futures market. Africa is the prime target of this large-scale scramble for farmland, which has seen the appropriation of an estimated thirty-four million hectares of land across the continent (Anseeuw et al 2011:4). The gatekeeper states and the institutions of global governance have been at the forefront of this great enclosure of the African commons, suggesting that large-scale mechanized agriculture provides the only means of closing the "yield gap" essential for food security and generating the capital needed for socio-economic development. But almost invariably, this new wave of industrial agriculture is oriented to the export market, and a large segment of it is devoted to the production 
of agrofuels. Africa's small subsistence producers are consequently being marginalized or evicted from their lands as an archipelago of large-scale commercial farms reconstitutes the rural socio-ecological landscape. The result has been the growing asymmetrical integration of Africa's farms into a global corporate agro-food complex that is further accentuating global climate change and the loss of biodiversity. Socially, this represents a profound transformation of agrarian social relations in the continent from the pre-existing pattern of "exploitation without dispossession" (Berry 1993) to one of "accumulation by dispossession" (Harvey 2003).

This concerted drive to commodify land and labor constitutes a monumental assault on Africa's independent producers and village communities. With little industry to absorb the displaced peasants, a vast rural reserve army of labor is emerging that has generated a steady exodus to urban centers already plagued by decaying infrastructure, growing social polarization, and informal sectors where an estimated seventy percent of Africa's laborers try to eke out a precarious existence. Unconnected with any real economic revolution comparable to the industrial revolution of the 19th century, this form of urbanization exhibits all the characteristics of cities in enclave economies. As Mike Davis observes, "urbanization has been more radically decoupled from industrialization, even from development per se, and in sub-Saharan Africa, from that supposed sine qua non of urbanization, rising agricultural productivity. The size of a city's economy, as a result, often bears surprisingly little relationship to its population size, and vice versa" (Davis 2006: 13). ${ }^{18}$ Far from being the motor of economic growth, the hypertrophy of Africa's cities reflects their status as the last refuge of the disinherited. In the meantime, rural discontent grows and the city itself generates new layers of the wretched of the earth that will undoubtedly form the social combustion of popular upheavals to come.

\section{Conclusion}

Africa is today in the throes of a profound social and economic transformation shaped by growing resource extraction, creeping peasant dispossession, and heightened levels of social polarization and ecological degradation that in some respects recall the late-nineteenth century era of high imperialism. But the record of decolonization has not been one of unrelieved decline, as so many of its current detractors imply. The first two decades after decolonization witnessed perceptible if modest social gains within the framework of the postwar boom in the worldeconomy and an international order of embedded liberalism. With the onset of the long downturn in the mid-1970s, a new pattern of neoliberal primitive accumulation emerged that effectively strangled Africa's weak economies. The shift in the global center of accumulation to East Asia has partially altered this context and generated growing demand for Africa's resources that has catalyzed a modest if uneven economic expansion. But if this restructuring is to be converted into an enduring social gain for Africa's citizens, the neoliberal reification of the market and the consequent downplaying of human agency, and the anaesthetizing effect this has had on critical thought, will all have to be overcome. The condition of Africa today is an outcome of its asymmetrical integration into the world system, and any credible alternatives beyond it will require a concerted effort to transform the relational structures of power that have continued to reproduce it.

\footnotetext{
${ }^{18}$ Some estimates suggest that by 2015, sub-Saharan Africa will have "332 million slum-dwellers," which constitutes about a third of the continent's population (Davis 2006, p. 19).
} 


\section{References}

Adas, Michael. 1990. Machines as the Measure of Man: Science, Technology, and Ideologies of Western Dominance. Ithaca: Cornell University Press.

African Development Bank (AfDB). 2014. www.africaneconomicoutlook.org/en. Accessed 5 July 2014.

Amin, Samir. 1992. "Underdevelopment and Dependency in Black Africa." Journal of Modern African Studies X: 503-24.

Amsden, Alice. 2007. Escape from Empire: The Developing World's Journey through Heaven and Hell. Cambridge: MIT Press.

Anderson, Perry. 2010. "Two Revolutions." New Left Review 61: 59-96.

Anseeuw, W.L., L. Wily, L. Cotula, and M. Taylor. 2011. "Land Rights and the Rush for Land: Findings of the Global Commercial Pressures on Land Research Project." Rome: International Land Coalition.

Appiah, Kwame A. 1993. In My Father's House: Africa in the Philosophy of Culture. Oxford: Oxford University Press.

Arrigh, Giovanni. 1994. The Long Twentieth-Century: Money, Power and the Origins of Our Time. London: Verso.

Arrighi, Giovanni. 2002. "The African Crisis: World-Systemic and Regional Aspects," New Left Review II/15: 24-31.

Arrighi, Giovanni. 2007. Adam Smith in Beijing: Lineages of the Twenty First Century. London: Verso.

Arrighi, Giovanni. 2012. "The World Economy and the Cold War: 1970-1990." Pp. 23-44 in The Cambridge History of the Cold War, Volume 3, edited by Melvyn P Leffler and Odd Ann Westand. Cambridge: Cambridge University Press.

Arrighi, Giovanni, Beverly J. Silver, and Benjamin D. Brewer. 2003. "Industrial Convergence, Globalization, and the Persistence of the North-South Divide." Studies in International Comparative Development 38 (1): 3-31.

Bayart, Jean-Francois. 1993. The State in Africa: The Politics of the Belly. Longman: London.

Ben Barka, Habiba and Mthuli Ncube. 2012. Political Fragility in Africa: Are Military Coups d'Etat a Never-Ending Phenomenon? Tunis: African Development Bank.

Bernstein, H. Ben Crow, M. Mackintosh, C. Martin (eds.) The Food Question: Profits Versus People. London: Earthscan Publications.

Berry, Sara. 1993. No Condition is Permanent: The Social Dynamics of Agrarian Change in Subs-Saharan Africa. Madison: University of Wisconsin Press.

Berry, Sara. 2002. "Debating the Land Question in Africa." Comparative Studies in Society and History 44 (4): 638-668.

Bond, Patrick. 2006. Looting of Africa: The Economics of Exploitation. London: Zed Books.

Brandt Commission. 1983. Common Crisis. London: Pan.

Brenner, Robert. 2006. The Economics of Global Turbulence: The Advanced Capitalist Economies from Long Boom to Long Downturn, 1945-2005. London: Verso.

Cammack, Paul. 2004. "What the World Bank Means by Poverty Reduction and Why It Matters." New Political Economy 9 (2): 189-211.

Carmody, Pádraig. 2011. The New Scramble for Africa. Cambridge: Polity Press.

Cooper, Frederick. 1993. "Africa and the World Economy." Pp. 84-201 in Confronting Historical Paradigms: Peasants, Labor, and the Capitalist World System in Africa and Latin 
America, edited by Frederick Cooper, Florencia E. Mallon, Steve J. Stern, Allen F. Isaacman and William Roseberry. Madison: University of Wisconsin Press.

Cooper, Frederick. 1996. Decolonization and African Society: The Labor Question in French and British Colonial Africa, 1945-1954. Cambridge: Cambridge University Press.

Cooper, Frederick. 2002. Africa since 1940. Cambridge: Cambridge University Press.

Cooper, Frederick. 2014. Africa in the World: Capitalism, Empire, Nation-State. Cambridge: Harvard University Press.

Davis, Mike. 1986. Prisoners of the American Dream. London: Verso.

Davis, Mike. 2006. Planet of Slums. London: Verso.

Davidson, Basil. 1992. The Black Man's Burden: Africa and the Curse of the Nation-State. New York: Times Books.

Davidson, Basil and Mahmood Mamdani. 1993. "The Sun Is Not Always Dead at Midnight." Monthly Review 45(3): 25-57.

Fairtrade. 2010. The Great Cotton Stich-Up. London: Fairtrade Foundation.

Ferguson, James. 1994. The Anti-Politics Machine: "Development," Depoliticization, and Bureaucratic Power in Lesotho. Minneapolis: University of Minnesota Press.

Ferguson, James. 1999. Expectations of Modernity: Myths and Meanings of Urban Life on the Zambian Copperbelt. Los Angeles: University of California Press.

Ferguson, James. 2006. Global Shadows: Africa in the Neoliberal World Order. Durham: Duke University Press.

Freund, Bill. 1998. The Making of Contemporary Africa: The Development of African Society Since 1800. Boulder, Co.: Lynne Rienner Publishers.

George, Susan. 1976. How the Other Half Die. London: Penguin Books.

Goody, Jack. 1971. Technology, Tradition and the State in Africa. London: Oxford University Press.

Juan Martinez-Alier, L. Temper, S. Munguti, P. Matiku et al. 2014. The Many Faces of Land Grabbing: Cases from Africa and Latin America. EJOLT Report No. 10.

Harvey, David. 2003. The New Imperialism. Oxford: Oxford University Press.

Hayden, Göran. 1980. Beyond Ujamaa in Tanzania. Berkeley: University of California Press.

Herbst, Jeffrey. 2000. States and Power in Africa: Comparative Lessons in Authority and Control. Princeton: Princeton University Press.

Hochschild, Adam. 1999. King Leopold's Ghost: A Story of Greed, Terror, and Heroism in Colonial Africa. Boston and New York: Houghton Mifflin.

Iliffe, John. 2007. Africans: The History of a Continent. Cambridge: Cambridge University Press.

International Monetary Fund (IMF). 2013. Sub-Saharan Africa: Keeping the Pace. Washington D.C.: International Monetary Fund.

Kleinknecht, Alfred, E. Mandel, I. Wallerstein, Eds. 1992. New Findings in Long-Wave Research. London: The Macmillan Press.

Knox, Paul and John Agnew. 1994. The Geography of the World Economy. London: Edward Arnold.

Lee, Ching Kwan. 2014. "The Specter of Global China." New Left Review 89: 29-65.

Leys, Colin. 1994. "Confronting the African Tragedy." New Left Review I/204: 33-47. . 1996. The Rise and Fall of Development Theory. London: James Curry Ltd.

Makki, Fouad. 2015. "Reframing Development Theory: Historical Capitalism as Uneven and Combined Process." Forthcoming in Theory \& Society. 
Mamdani, Mahmood. 2009. Saviors and Survivors: Darfur, Politics, and the War on Terror. New York: Pantheon Books.

Mamdani, Mahmood. 1986. "Peasants and Democracy in Africa." New Left Review I/15: 37-49.

Mandel, Ernest. 1995. Long Waves of Capitalist Development: A Marxist Interpretation. London: Verso.

Manji, Ambreena. 2006. The Politics of Land Reform in Africa: From Communal Tenure to Free Markets. London: Zed Books.

Mazrui, Ali. 1999. "From Slave Ship to Space Ship: From Marginalization to Globalization." African Studies Quarterly 2 (4): 5-11.

McMichael, Philip. 2000.. "World-Systems Analysis, Globalization and Incorporated Comparisons." Journal of World-Systems Research 6:3: 668-690.

Mkandawire, Thandika and Charles C. Soludo. 1999. Our Continent, Our Future. Trenton, NJ: Africa World Press.

Mudimbe, V.Y. 1988. The Invention of Africa: Gnosis, Philosophy and the Order of Knowledge. Indianapolis: University of Indiana Press.

Murray, Roger. 1966. "Militarism in Africa," New Left Review I/38, pp. 35-59.

Ncube, Mthuli. 2013. "Hemorrhage of Illicit Financial Flows in Africa." http://www.afdb.org/en/blogs/afdb-championing-inclusive-growth-acrossafrica/post/hemorrhage-of-illicit-financial-flows-in-africa-11859/. Accessed on 20 February 2014.

OECD. 2007. International Migration Outlook.

OECD-UNDESA. 2013. World Migration in Figures. http://www.oecd.org/els/mig/WorldMigration-in-Figures.pdf

Piot, Charles. 2010. Nostalgia for the Future: West Africa after the Cold War. Chicago: University of Chicago Press.

Quan, H. L. T. 2012. Growth Against Democracy: Savage Developmentalism in the Modern World. Lanham, Md: Lexington Books.

Rakotoarisoa, M., M. Lafrate, and M. Paschali. 2011. Why Has Africa Become a Net Food Importer? Rome: United Nations Food and Agricultural Organization.

Rodney, Walter. 1974. How Europe Underdeveloped Africa. Washington DC: Howard University Press.

Rosenberg, Justin. 2006. "Why Is There No International Historical Sociology?" European Journal of International Relations 12 (3): 307-40.

Rosenberg, Justin. 2013. "The 'Philosophical Premises' of Uneven and Combined Development." Review of International Studies 39 (3): 569-97.

Schumpeter, J. 1982 [1961]. The Theory of Economic Development. New York: Transaction Publishers.

Southhall, Roger and Henning Melber (eds.). 2009. A New Scramble for Africa? Imperialism, Investment and Development. Scottsville: University of KwaZulu-Natal Press.

Steinmetz, George. 2007. The Devil's Handwriting: Precoloniality and the German Colonial State in Qingdao, Samoa, and Southwest Africa. Chicago: University of Chicago Press.

Tomich, Dale W. 2004. Through the Prism of Slavery: Labor, Capital and the World Economy. Oxford: Rowman\& Littlefield.

UNCTAD. 2000. Capital Flows and Growth in Africa. Geneva: United Nations.

UNCTAD. 2003. Economic Development in Africa: Trade Performance and Commodity Dependence. New York and Geneva: United Nations. 
UNCTAD. 2013. Global Investment Trends Monitor. Geneva: United Nations.

UNIDO. 2011. Economic Development in Africa: Fostering Industrial Development in Africa in the New Global Environment. New York: United Nations.

United Nations. 2013. World Economic Situation and Prospects. New York: United Nations.

Wade, Robert. 1996. "Japan, the World Bank and the Art of Paradigm Maintenance: The East Asian Miracle in Political Perspective." New Left Review I/217: 3-37.

Wilder, Gary. 2015. Freedom Time: Negritude, Decolonization, and the Future of the World. Durham: Duke University Press.

Wallerstein, Immanuel. 1986. Africa and the Modern World. Trenton, NJ: Africa World Press.

Wallerstein, Immanuel. 1991. Unthinking Social Science: The Limits of Nineteenth Century Paradigms. Philadelphia: Temple University Press.

Wolpe, Harold. 1995. "Capitalism and Cheap Labour Power in South Africa: From Segregation to Apartheid." Pp. 60-90 in Segregation and Apartheid in Twentieth Century South Africa, edited by William Beinart and Saul Dubow. New York: Routledge.

World Bank. 2000. Can Africa Claim the 21 st Century? Washington, D.C.: World Bank.

World Bank. 2014. Africa Overview (Updated March 27).

http://www.worldbank.org/en/region/afr/overview. 